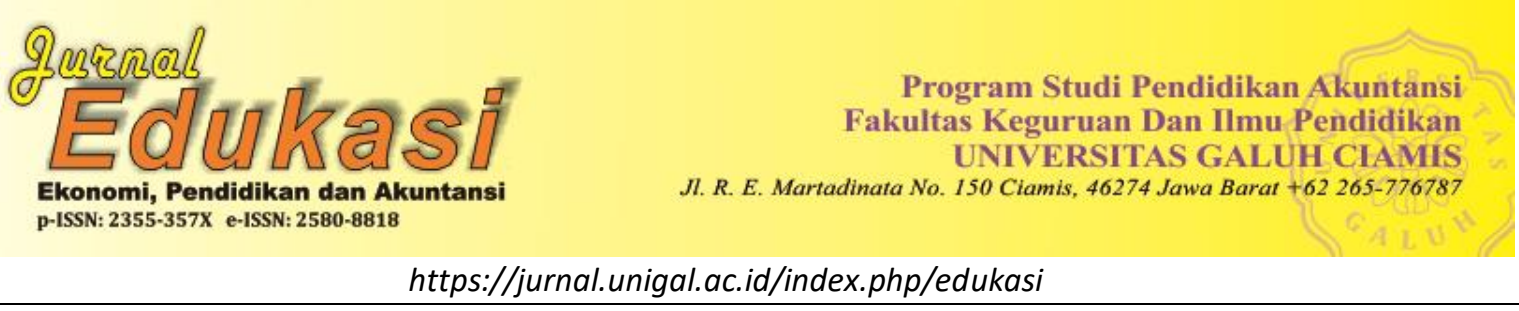

\title{
ANALISIS KREDIT PERBANKAN, BELANJA PUBLIK, PERTUMBUHAN PENDUDUK, DAN KETIMPANGAN PENDAPATAN IMPLIKASINYA TERHADAP KEMISKINAN
}

\author{
Oleh: \\ Sukomo \\ Program Studi Pendidikan Akuntansi Universitas Galuh, Indonesia \\ Email:sukomo@yahoo.com \\ Sejarah Artikel: Diterima September 2019, Disetujui Oktober 2019, Dipublikasikan November 2019
}

\begin{abstract}
ABSTRAK
Permasalahan dalam penelitian ini adalah bagaimana posisi kredit perbankan, belanja untuk sektor publik dengan proxy belanja modal, pertumbuhan penduduk, dan ketimpangan pendapatan mempengaruhi tingkat kemiskinan di Jawa Barat. Adapun tujuan penelitian ini adalah untuk mengkaji dan menganalisis posisi kredit perbankan, belanja untuk sektor publik dengan proxy belanja modal, pertumbuhan penduduk, dan ketimpangan pendapatan implikasinya terhadap tingkat kemiskinan di Jawa Barat. Tipe penelitian yang digunakan adalah penelitian eksplanatoris dengan sifat penelitiannya adalah verifikatif. Data yang digunakan adalah data panel yang merupakan gabungan data time series tahun 2005-2015 dan data cross saction daerah Kabupaten dan Kota di Jawa Barat. Adapun teknik analisis data yang digunakan adalah teknik Panel Data Regression Model dengan metode Two Stage Least Square dengan pendekatan random effect. Hasil penelitian posisi kredit perbankan, Pengeluaran pemerintah untuk belanja publik dengan proxy belanja modal, pertumbuhan penduduk, dan ketimpangan pendapatan masyarakat berpengaruh signifikan terhadap tingkat kemiskinan di kabupaten dan kota di Jawa Barat. Temuan hasil penelitian adalah: (1) Terdapat hubungan yang positif dan signifikan antara posisi kredit perbankan dengan tingkat kemiskinan di Kabupaten dan Kota di Jawa Barat. (2) Terdapat hubungan yang negatif dan signifikan antara pengeluaran pemerintah untuk belanja publik dengan proxy belanja modal dengan tingkat kemiskinan di Kabupaten dan Kota di Jawa Barat. (3) Terdapat hubungan yang positif dan signifikan antara pertumbuhan penduduk dengan tingkat kemiskinan di Kabupaten dan Kota di Jawa Barat. (4) Terdapat hubungan yang negatif dan signifikan antara ketimpangan pendapatan masyarakat yang diukur dengan koefisien Gini dengan tingkat kemiskinan di Kabupaten dan Kota di Jawa Barat.
\end{abstract}

Kata Kunci: Kemiskinan, Posisi Kredit Perbankan, Belanja Modal, Pertumbuhan Penduduk, Koefisien Gini

\section{ABSTRACT}

The problem in this study is how the banking credi position, spending for the public sector with a proxy for capital expenditure, population growth, and income inequality affect poverty levels in West Java. The purpose of this study is to examine and analyze the banking credi position, spending for the public sector with a proxy for capital expenditure, population growth, and income inequality implications for poverty levels in West Java. The research type uses explanatory research which the nature of the research is verification. The data used is panel data which is a combination of time series data in 2005-2015 and cross saction data of regencies and cities in West Java. The data analysis technique used is the technique Panel Data Regression Model with the Two Stage Least Square method with a random effect approach. The results of the study of the banking credit position, government spending for public sector with a proxy for capital expenditure, population growth, and income inequality of community significantly influence poverty levels in regencies and cities in West Java. The findings of the study are: (1) There is a positive and significant relationship between the 
banking credit position with the level of poverty in regencies and cities in West Java. (2) There is a negative and significant relationship between government spending for public sector with a proxy for capital expenditure with the level of poverty in regencies and cities in West Java. (3) There is a positive and significant relationship between population growth with the level of poverty in regencies and cities in West Java. (4) There is a negative and significant relationship between income inequality of community as measured by the Gini coefficient with the level of poverty in regencies and cities in West Java.

\section{Keywords: Poverty, Banking Credit Position, Capital Expenditure, Population Growth, Gini Coefficient .}

\section{PENDAHULUAN}

Isu sentral dalam penelitian ini adalah apakah perkembangan kredit perbankan yang disalurkan kepada masyarakat dan perkembangan besarnya belanja untuk sektor publik dengan proxy besarnya belanja modal yang dilakukan oleh pemerintah daerah mampu mengurangi tingkat kemiskinan.

Penelitian ini dilakukan di Provinsi Jawa Barat, dengan pertimbangan: (1) Ekspansi kredit perbankan di Jawa Barat selama Tahun 2011 sampai Tahun 2015 jumlahnya terbesar kedua dari 33 provinsi di Indonesia setelah DKI Jakarta, yaitu untuk Jawa Barat Tahun 20112015 masing-masing sebesar Rp. 275.961 Milyar; Rp. 342.802 Milyar; Rp. 415.389 Milyar: Rp. 496.415 Milyar; dan Rp. 526.306 Milyar. Sedangkan ekspansi kredit perbankan di DKI Jakarta selama Tahun 2011 sampai Tahun 2015 adalah masing-masing sebesar Rp. 743.686 Milyar; Rp. 896.903 Milyar; Rp. 1.090.294 Milyar; Rp. 1.184.184 Milyar; dan Rp. 1.239.972 Milyar. (2) Besarnya belanja untuk sektor publik dengan proxy besarnya belanja modal selama lima tahun terakhir yaitu Tahun 2011 sampai Tahun 2015 Jawa Barat menduduki posisi ke-9 antar Provinsi di Indonesia, yaitu Tahun 2011 sebesar Rp. 719 Milyar; Tahun 2012 sebesar Rp. 1.135 Milyar; Tahun 2013 sebesar Rp. 1.273 Milyar; Tahun 2014 sebesar Rp. 1.360 Milyar; dan Tahun 2015 sebesar Rp. 2.299 Milyar.

Pertimbangan berikutnya (3) Tingkat Kemiskinan, selama periode Tahun 2011 sampai Tahun 2015 di Jawa Barat berada pada posisi sebagai berikut: pada tahun 2011 tingkat kemiskinan di Jawa Barat berada pada posisi ke-16 diantara provinsi yang ada di Indonesia yaitu sebesar $10,65 \%$, begitu juga pada tahun 2012 masih di posisi ke-16 yaitu sebesar 9,89\%, pada tahun 2013 posisinya menjadi ke-15 dengan tingkat kemiskinannya sebesar 9,61\%, begitu juga tahun 2014 posisinya tetap ke-15 dengan tingkat kemiskinan sebesar 9,18\%, dan tahun 2015 posisinya menjadi ke-16 dengan tingkat kemiskinan sebesar 9,57\%.

Jawa Barat adalah salah satu dari 33 Provinsi yang ada di Indonesia yang merupakan penyangga ibu kota negara Indonesia, diharapkan mempunyai kemajuan ekonomi yang tinggi, sehingga bisa mendorong perekonomian nasional bisa berkembang dengan baik. Kenyataannya tingkat kemiskinan di Jawa Barat, perkembangannya masih relatif tinggi. Perkembangan tingkat kemiskinan di Jawa Barat selama 8 tahun terakhir yaitu dari tahun 2008 sampai tahun 2015 rata-rata setiap tahunnya adalah sebesar 10,52\%, jika dibandingkan dengan rata-rata tingkat kemiskinan Nasional, Jawa Barat masih lebih rendah, sebab rata-rata tingkat kemiskinan Nasional dalam periode yang sama setiap tahunnya sebesar $12,58 \%$.

Keterkaitan antara perkembangan posisi kredit perbankan dengan tingkat kemiskinan, dapat dijelaskan bahwa di satu sisi perkembangan posisi kredit perbankan setiap tahunnya meningkat tetapi di sisi lain perkembangan tingkat kemiskinan menurun ini berarti perkembangan posisi kredit perbankan dan perkembangan tingkat kemiskinan di Jawa Barat kecenderungannya berlawanan.

Fenomena empiris keterkaitan antara perkembangan Posisi Kredit Perbankan dengan perkembangan Tingkat Kemiskinan selama periode 2008 sampai tahun 2015 di Jawa Barat, jika dibandingkan dengan hasil riset yang telah dilakukan oleh para peneliti, ada yang hasilnya sama dan ada yang berbeda.

Sejak tahun 2007, istilah belanja sektor publik tidak digunakan lagi di Indonesia. oleh karena itu pada penelitian ini belanja untuk sektor publik digunakan proxy belanja modal. Perkembangan besarnya belanja modal selama periode tahun 2008 sampai tahun 2015 mengalami peningkatan setiap tahunnya. 
kecuali pada tahun 2011 mengalami penurunan. Pada tahun 2009 dan tahun 2010 besarnya belanja modal meningkat masing-masing $105,08 \%$ dan $45,45 \%$, sedangkan pada tahun 2011 besarnya belanja modal mengalami penurunan dibandingkan dengan tahun 2010 yaitu sebesar $31,91 \%$, dan tahun 2012, 2013, 2014 dan 2015 besarnya belanja modal mengalami kenaikan kembali, masing-masing sebesar $57,86 \%, 12,16 \%, 6,83 \%$, dan $69,04 \%$. Jika dilihat dari rata-ratanya besarnya belanja modal setiap tahunnya sebesar Rp. 1.115 Milyar, atau rata-rata kenaikan setiap tahunnya selama periode tahun 2008 sampai tahun 2015 sebesar 37,79\%.

Keterkaitan antara perkembangan belanja modal sebagai proxy dari belanja untuk sektor publik dengan perkembangan tingkat kemiskinan di Jawa Barat selama periode tahun 2008 sampai tahun 2015, dapat dijelaskan bahwa di satu sisi perkembangan belanja modal perkembangannya cenderung meningkat, tetapi di sisi lain perkembangan tingkat kemiskinan setiap tahunnya cenderung menurun, ini berarti perkembangan belanja modal dan perkembangan tingkat kemiskinan di Jawa Barat kecenderungannya berlawanan.

Fenomena empiris keterkaitan antara perkembangan belanja modal dengan tingkat Kemiskinan selama periode 2008 sampai tahun 2015 di Jawa Barat, jika dibandingkan dengan hasil riset yang telah dilakukan oleh para peneliti, ada yang hasilnya sama dan ada yang berbeda.

Perkembangan pertumbuhan penduduk di Jawa Barat selama periode tahun 2008 sampai tahun 2015 cenderung menurun. Rata-rata pertumbuhan penduduk setiap tahunnya sebesar $1,29 \%$. Keterkaitan pertumbuhan penduduk dengan tingkat kemiskinan di Jawa Barat selama periode tahun 2008 sampai tahun 2015, dapat dijelaskan bahwa di satu sisi pertumbuhan penduduk setiap tahunnya cenderung menurun, di sisi lain perkembangan tingkat kemiskinan setiap tahunnya cenderung menurun, ini berarti pertumbuhan penduduk dan perkembangan tingkat kemiskinan di Jawa Barat kecenderungannya sama.

Perkembangan ketimpangan pendapatan masyarakat yang diukur dengan koefisien gini di Jawa Barat selama periode tahun 2008 sampai tahun 2015 kecenderungannya meningkat setiap tahunnya kecuali tahun 2013 dan tahun 2015 nilai koefisien gini-nya turun. Rata-rata koefisien gini setiap tahunnya sebesar
$0,372 \%$. Keterkaitan antara perkembangan koefisien gini dengan tingkat kemiskinan di Jawa Barat selama periode tahun 2008 sampai tahun 2015, dapat dijelaskan bahwa di satu sisi perkembangan koefisien gini setiap tahunnya cenderung meningkat, tetapi di sisi lain perkembangan tingkat kemiskinan setiap tahunnya menurun, ini berarti perkembangan koefisien gini dan perkembangan tingkat kemiskinan di Jawa Barat kecenderungannya berlawanan.

Berdasarkan fenomena empiris di Jawa Barat mengenai keterkaitan antara kemiskinan, posisi kredit perbankan, belanja modal, pertumbuhan penduduk, dan koefisien gini yang telah dijelaskan sebelumnya, dapat diidentifikasi bahwa keterkaitan fenomena data secara empiris posisi kredit perbankan, belanja modal, pertumbuhan penduduk dan rasio gini dengan tingkat kemiskinan di Jawa Barat fenomenanya adalah perkembangan posisi kredit perbankan dan perkembangan belanja modal dengan perkembangan tingkat kemiskinan berlawanan, sedangkan pertumbuhan penduduk dan perkembangan gini rasio dengan perkembangan tingkat kemiskinan sama. Fenomena ini jika dibandingkan dengan hasil riset yang telah dilakukan oleh para peneliti di tempat lain hasilnya ada yang sama dan ada yang berbeda.

Permasalahannya adalah bagaimana pengaruh posisi kredit perbankan, belanja untuk sektor publik dengan proxy belanja modal, pertumbuhan penduduk, dan ketimpangan pendapatan terhadap tingkat kemiskinan di Jawa Barat?

Tujuan penelitian ini adalah untuk mengkaji dan menganalisis pengaruh posisi kredit perbankan, belanja untuk sektor publik dengan proxy belanja modal, pertumbuhan penduduk, dan ketimpangan pendapatan terhadap tingkat kemiskinan di Jawa Barat.

\section{METODE PENELITIAN Tipe Penelitian}

Tipe penelitian yang digunakan dalam penelitian ini adalah penelitian eksplanatoris (explanatory research). Tipe penelitian ini relevan digunakan untuk penelitian-penelitian sosial yang mencoba melihat, mengukur, dan menguji hubungan kausalitas antar variabel. Tipe penelitian ini juga sesuai digunakan bagi penelitian-penelitian yang diarahkan untuk menguji hipotesis (hypothesis testint), yaitu menganalisis pengaruh atau hubungan antara 
variabel-variabel berdasarkan data empirik melalui pengujian hipotesis.

Sifat penelitiannya adalah verifikatif, yaitu meneliti hubungan, keterkaitan, dan pengaruh antara variabel bebas (independent variable) terhadap variabel terikat (dependent variable) yang diteliti. Dalam kaitan tersebut, akan dilakukan pengujian ekonometrika untuk memperoleh kesimpulan penelitian.

\section{Variabel Penelitian}

Variabel dalam penelitian ini dapat diklasifikasikan menjadi dua, yaitu variabel independen dan variabel dependen. Variabel independen dalam penelitian ini adalah Posisi Kredit Perbankan, pengeluaran pemerintah untuk belanja sektor publik dengan proxy belanja modal, pertumbuhan penduduk, dan ketimpangan pendapatan, sedangkan variabel dependen dalam penelitian ini adalah kemiskinan.

\section{Jenis dan Sumber Data}

Dalam penelitian ini, data yang digunakan sebagai bahan analisis adalah data sekunder dalam bentuk data panel (pooled data) dari berbagai sumber data, seperti Badan Pusat Statisk (BPS) Jawa Barat, Badan Perencana Daerah (BAPEDA) Jawa Barat, dan Bank Indonesia Kantor Jawa Barat. Data panel atau sering juga disebut sebagai data pooling atau data longitudinal adalah gabungan atau kombinasi data runtut waktu ( time series) dengan data silang tempat (cross section).

Pemilihan data panel dalam penelitian ini sangat berkaitan dengan tujuan penelitian, yaitu untuk mengestimasi 26 Kabupaten dan Kota di Jawa Barat selama periode 2005-2015. Penggunaan data panel sangat tepat karena data panel merupakan gabungan antara data time series yaitu sekumpulan data yang relevan selama kurun waktu 2005-2015 dan data cross section yaitu sebanyak 26 Kabupaten dan Kota di Jawa Barat.

\section{Teknik Analisis Data}

Dalam pengujian hipotesis digunakan teknik analisis kuantitatif-deskriptif maupun kuntitatif-induktif. Teknik kuantitatif-deskriptif misalnya penyajian tabel-tabel, rasio, dan persentase. Sedangkan teknik kuantitatifinduktif dalam penelitian ini digunakan model regresi dengan menggunakan pooling data yang merupakan gabungan data time series tahun
2005-2015 dan data cross saction daerah Kabupaten dan Kota di Jawa Barat.

Untuk menguji pengaruh posisi kredit perbankan, belanja untuk sektor publik dengan proxy belanja modal, pertumbuhan penduduk, dan ketimpangan pendapatan terhadap kemiskinan di Provinsi Jawa Barat digunakan teknik analisis regresi dengan data panel (Panel Data Regression Model) dengan metode Two Stage Least Square (TSLS) dengan pendekatan efek acak (random effect).

Spesifikasi model yang dipergunakan dalam penelitian ini adalah model persamaan struktural, yaitu sebagai berikut: $-\beta_{4} \mathrm{KG}_{\mathrm{it}}+\mathrm{e}_{\mathrm{it}}$

ceteris paribus.

$$
\mathrm{KEM}_{\mathrm{it}}=\beta_{0}-\beta_{1} \mathrm{PKP}_{\mathrm{it}}-\beta_{2} \mathrm{GEP}_{\mathrm{it}}+\beta_{3} \mathrm{GP}_{\mathrm{it}}
$$

$$
\beta_{1}>0 ; \quad \beta_{2}>0 ; \quad \beta_{3}>0 ; \quad \beta_{4}>0 ;
$$

\section{Dimana:}

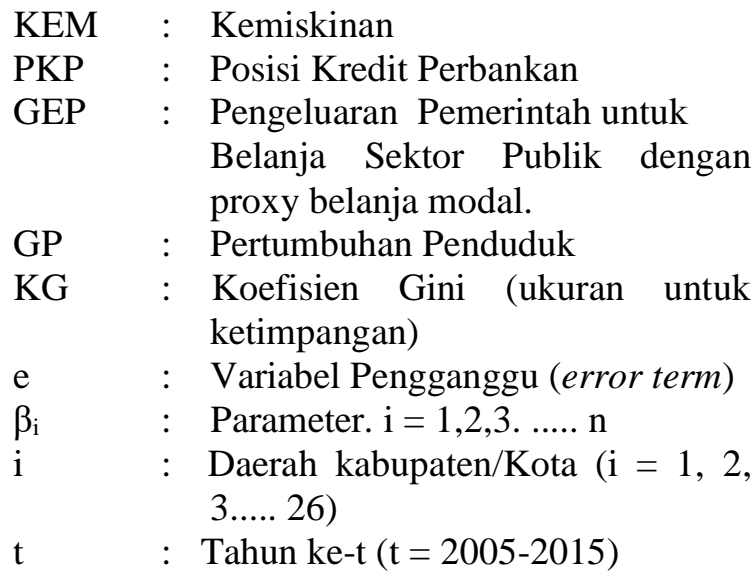

Selanjutnya akan dilakukan:

(1) Uji-t

$$
t=b_{i} / S b
$$

Dimana:

$b_{i}=$ Galat Baku Koefisien $b_{i}$

$\mathrm{Sb}_{\mathrm{i}}=$ Taksiran Galat Baku Koefisien $b_{\mathrm{i}}$

(2) Uji-F

$$
\begin{aligned}
& F=\frac{J K(\operatorname{Reg}) / k}{J K(S) /(n-k-1)} \\
& \text { Dimana: } \\
& \text { JK(Reg) = Jumlah Kuadrat Regresi } \\
& \mathrm{JK}(\mathrm{S}) \quad=\text { Jumlah Kuadrat Sisa } \\
& \mathrm{k}=\text { Jumlah Variabel Independen } \\
& \mathrm{n}=\text { Banyaknya sampel. }
\end{aligned}
$$

\section{(3) Uji R $\mathbf{R}^{2}$ dan Uji Adj-R}

a. Uji $\mathbf{R}^{2}$ : 


$$
R^{2}=\frac{J K(\mathrm{Reg})}{\sum y^{2}}
$$

b. Uji Adj-R

$$
\bar{R}^{2}=1-\frac{\sigma^{2}}{S_{y}^{2}}
$$

Dimana:

$$
\begin{aligned}
& \sigma^{2}=\text { Varians Residual } \\
& S_{y}^{2}=\text { Varians Sampel }
\end{aligned}
$$

\section{HASIL PENELITIAN DAN}

\section{PEMBAHASAN}

Pada model Kemiskinan ini diduga bahwa kemiskinan dipengaruhi oleh posisi kredit perbankan (PKP), pengeluaran pemerintah untuk belanja publik dengan proxy belanja modal (GEP), pertumbuhan penduduk (GP), dan koefisien Gini (KG).

Teknik analisis yang digunakan adalah metode estimasi Two Stage Least Square (TSLS), dengan pendekatan Random Effect Model (FEM.)

Adapun model empiris hasil estimasi pengaruh posisi kredit perbankan (PKP), pengeluaran pemerintah untuk belanja publik proxy belanja modal (GEP), pertumbuhan penduduk (GP), dan koefisien Gini (GR) terhadap kemiskinan (KEM) di Kabupaten dan Kota di Jawa Barat adalah sebagai berikut :

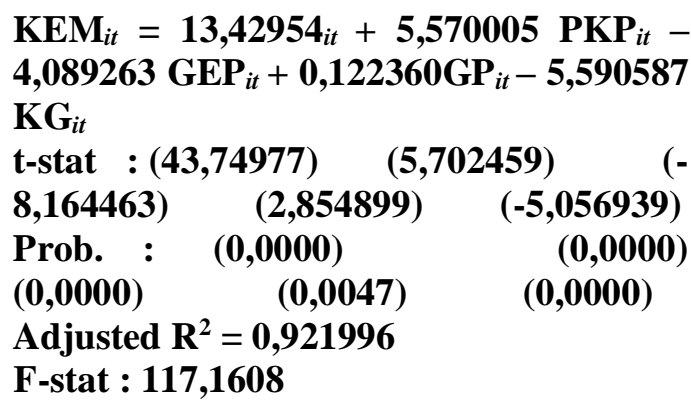

Dari persamaan regresi yang diperoleh dapat dijelaskan adanya hubungan yang berbanding lurus antara posisi kredit perbankan dengan kemiskinan. Terlihat koefisien regresi untuk variabel posisi kredit perbankan bertanda positif sebesar 5,570005. Ini mengindikasikan bahwa kredit perbankan yang disalurkan kepada masyarakat di Kabupaten dan Kota di Jawa Barat, baik dilihat dari jenisnya, yaitu kredit modal kerja, kredit investasi, maupun kredit konsumsi diprediksi belum mampu menurunkan tingkat kemiskinan di Kabupaten dan Kota di Jawa Barat.
Hasil penelitian ini tidak sejalan dengan hasil penelitian yang telah dilakukan oleh Jalilian \& Kirk Patrick (2001), Honohan (2004), Zhuang, Juzhong et.al. (2009), dan Pradhan, Rudra P (2010), serta Odhiambo (2010).

Menurut Jalilian \& Kirk Patrick (2001), bahwa jasa sektor keuangan pada umumnya meningkatkan pertumbuhan pendapatan, dengan memperluas penyediaan jasa keuangan yang dapat diakses oleh masyarakat miskin dan akan meningkatkan pertumbuhan pendapatan bagi masyarakat miskin, sehingga memiliki dampak langsung pada pengurangan kemiskinan.

Honohan (2004) menemukan hubungan negatif antara pengembangan sektor keuangan dengan jumlah kemiskinan. Ini berarti dengan membaiknya sektor keuangan dengan proxy kredit maka tingkat kemiskinan bisa menurun.

Zhuang (2009) meneliti keterkaitan antara pengembangan sektor keuangan dengan pertumbuhan ekonomi dan kemiskinan, menyimpulkan bahwa sektor keuangan akan mempengaruh kemiskinan bisa melalui dua saluran. yaitu:

1. Secara tidak langsung.

Pengembangan sektor keuangan mendukung pengurangan kemiskinan adalah melalui pertumbuhan ekonomi. Banyak yang percaya bahwa pertumbuhan ekonomi dapat mengurangi kemiskinan absolut. Dampak dari pertumbuhan terhadap pengurangan kemiskinan melalui beberapa cara: (1) Pertumbuhan ekonomi bisa menghasilkan pekerjaan untuk yang miskin; (2) Tingkat pertumbuhan bisa mengurangi perbedaan dalam upah antara tenaga kerja yang trampil dan tenaga kerja yang tak terampil pada suatu tahap perkembangan tertentu, hal ini bisa bermanfaat bagi masyarakat miskin; (3) Pertumbuhan yang tinggi bisa menghasilkan pajak yang tinggi, sehingga memberikan peluang bagi pemerintah untuk mengalokasikan lebih banyak sumber daya fiskal di belanja sosial seperti kesehatan, pendidikan, dan perlindungan sosial, karenanya akan menguntungkan masyarakat miskin; dan masyarakat miskin juga mampu menginvestasikan lebih banyak di dalam modal manusia; (4) Ketika akumulasi modal meningkat dengan pertumbuhan ekonomi yang tinggi, maka akan lebih banyak dana yang tersedia untuk masyarakat miskin 
melakukan pinjaman untuk investasi sehinga meningkatkan penghasilan mereka.

2. Secara langsung

Secara langsung masyarakat miskin bisa mengakses sektor keuangan dengan memanfaatkan jasa sektor keuangan, sehingga bisa berdampak pada: (1) perluasan kesempatan kerja dan kesempatan berusaha, baik usaha kecil maupun usaha sendiri (informal); (2) peluang investasi pada modal manusia; dan (3) peluang peningkatan investasi. Dari ketiga dampak tersebut, maka akan menghasilkan pendapatan masyarakat miskin akan meningkat, sehingga kemiskinan bisa berkurang.

Hasil penelitian Odhiambo (2010) mengenai keterkaitan pengembangan sektor keuangan dengan proxy rasio persediaan uang beredar terhadap GDP(M2/GDP), rasio kredit domestik ke sektor swasta terhadap GDP atau (domestic credit to the private sector as a ratio of gross domestic product (DPC/GDP), dan domestic money bank assets (DMBA) dengan tingkat kemiskinan di Zambia dengan menggunakan data periode tahun 1969-2006, menyimpulkan bahwa adanya hubungan kausal antara pengembangan sektor keuangan dengan pengurangan kemiskinan di Zambia. Ketika persediaan rasio uang beredar (M2/GDP) digunakan sebagai proxy untuk pengembangan keuangan, bahwa pengurangan kemiskinan tampaknya menyebabkan pengembangan sektor keuangan. Namun. ketika DCP dan DMBA digunakan, pengembangan keuangan menyebabkan pengurangan kemiskinan.

Pradhan (2010) mengkaji hubungan kausal antara pengembangan sektor keuangan. pertumbuhan ekonomi dan pengurangan kemiskinan di India selama 1951-2008. Hasil penelitian menemukan adanya hubungan jangka panjang keseimbangan antara pengembangan sektor keuangan, pertumbuhan ekonomi dan pengurangan kemiskinan.

Untuk variabel pengeluaran pemerintah untuk belanja publik (GEP) dengan proxy belanja modal, dari persamaan regresi yang diperoleh dapat dijelaskan adanya hubungan yang berbanding terbalik antara perubahan pengeluaran pemerintah untuk belanja publik dengan kemiskinan. Terlihat koefisien regresi untuk variabel pengeluaran pemerintah untuk belanja publik negatif sebesar 4,089263. Jadi pengeluaran pemerintah untuk belanja publik dengan proxy belanja modal, diprediksi mampu menurunkan tingkat kemiskinan di Kabupaten dan Kota di Jawa Barat pada saat variabel lainnya tidak berubah (ceteris paribus) selama periode penelitian. Ini mengindikasikan bahwa pengeluaran pemerintah untuk belanja publik yang dibelanjakan dalam bentuk belanja modal oleh Kabupaten dan Kota di Jawa Barat diprediksi dapat menurunkan tingkat kemiskinan.

Hasil penelitian ini tidak sejalan dengan hasil penelitian yang telah dilakukan Bidani dan Ravalion (1997), Fan, Hazel dan Thorat (1999), Laabas dan Limam (2004), dan Fan, Shenggen (2007).

Bidani dan Ravallion (1997) yang melakukan studi terhadap 35 negara berkembang, menemukan adanya hubungan yang signifikan secara statistik antara belanja publik untuk kesehatan dengan kemiskinan. Mereka menemukan bahwa derajat kesehatan penduduk miskin relatif lebih buruk dibandingkan dengan rata-rata penduduk, dan karena itu adanya perbedaan dalam belanja publik untuk kesehatan cenderung lebih berarti atau bermanfaat bagi penduduk miskin.

Fan (1999) menganalisis hubungan antara pengeluaran pemerintah, pertumbuhan ekonomi, dan kemiskinan di daerah perdesaan di India. Hasil studi ini menunjukan bahwa peningkatan investasi pemerintah di sektor pertanian dan infrastruktur perdesaan, serta pengeluaran untuk pendidikan dan kesehatan mempunyai dampak nyata terhadap kemiskinan. Bahkan pengeluaran untuk pembangunan jalan mempunyai dampak paling besar terhadap penurunan kemiskinan.

Laabas dan Limam (2004) meneliti dampak pengeluaran pemerintah. Kemiskinan, ketimpangan, dan pertumbuhan ekonomi di negara-nagara Arab (Mesir, Yordania, Maroko, Mauratania, Tunisia, Yaman, dan Ajazair) selama tahun 1988-1999. Kesimpulan yang dihasilkan oleh penelitian ini adalah: (i) pengeluaran pemerintah memberi dampak terhadap kemiskinan secara tidak langsung melalui dampaknya terhadap distribusi pendapatan dan rata-rata pengeluaran; (ii) tidak seperti yang dipercaya secara umum, kebijakan publik yang diarahkan untuk meningkatkan distribusi pendapatan adalah lebih efektif dalam mempengaruhi kemiskinan dibandingkan dengan kebijakan yang ditargetkan untuk meningkatkan pertumbuhan ekonomi dan konsumsi rata-rata.

Fan (2007) membandingkan hasil penelitian di India dengan di China mengenai 
pengaruh belanja publik terhadap pertumbuhan ekonomi dan kemiskinan, dan menyimpulkan bahwa di India, belanja publik untuk jalan di perdesaan dan untuk riset pertanian mempunyai pengaruh yang terbesar untuk meningkatkan pertumbuhan ekonomi dan penurunan kemiskinan. Sedangkan di China belanja publik untuk R\&D pertanian dan untuk pendidikan dasar mempunyai pengaruh yang terbesar terhadap pertumbuhan ekonomi dan penurunan kemiskinan.

Hasil penelitian ini tidak sejalan dengan hasil penelitian Dollar dan Kraay (2001), mereka mengamati dampak kebijakan publik seperti stabilitas makro-ekonomi, disiplin pajak, serta belanja publik untuk kesehatan dan pendidikan terhadap kemiskinan. Mereka menemukan bahwa kuat dugaan, kebijakan propoor seperti belanja publik untuk kesehatan dan pendidikan tidak mempunyai dampak yang signifikan terhadap pendapatan kaum miskin. Mereka bahkan menyimpulkan bahwa kebijakan publik ini harus menjadi pusat dari seluruh program yang diarahkan untuk mengentaskan kemiskinan, sebab menurut mereka, belanja publik di negara-negara berkembang seringkali justru hanya memberi manfaat bagi kelompok menengah dan kaya daripada kelompok miskin.

Untuk variabel pertumbuhan penduduk (GP), dari persamaan regresi yang diperoleh dapat dijelaskan adanya hubungan yang berbanding lurus antara perubahan pertumbuhan penduduk dengan kemiskinan. Terlihat koefisien regresi untuk variabel pertumbuhan penduduk positif sebesar 0,122360 . Jadi setiap terjadi kenaikan satu persen pertumbuhan penduduk, diprediksi dapat menaikan tingkat kemiskinan Kabupaten dan Kota di Jawa Barat sebesar 0,179087\% pada saat variabel lainnya tidak berubah (ceteris paribus) selama periode penelitian. Ini mengindikasikan bahwa pertumbuhan penduduk di Kabupaten dan Kota di Jawa Barat diprediksi dapat menaikan tingkat kemiskinan.

Menurut Kuncoro (2003), ada dua pandangan yang berbeda mengenai pengaruh penduduk pada pembangunan. Pertama, adalah pandangan pesimis yang berpendapat bahwa penduduk (pertumbuhan penduduk yang pesat) dapat mengantarkan dan mendorong terjadinya pengurasan sumber daya, kekurangan tabungan, kerusakan lingkungan, kehancuran ekologis yang kemudian dapat memunculkan masalah- masalah sosial, seperti kemiskinan, keterbelakangan, dan kelaparan (Ehrlich. 1981). Kedua adalah pandangan optimis yang berpendapat bahwa penduduk adalah asset yang memungkinkan untuk mendorong pengembangan ekonomi dan promosi inovasi teknologi dan institusional, sehingga dapat mendorong perbaikan kondisi sosial (Thomas, et.al. 2001). Ini berarti disatu sisi pertumbuhan penduduk bisa berpengaruh terhadap peningkatan kemiskinan. tetapi bisa juga dianggap sebagai asset untuk meningkatkan kegiatan ekonomi masyarakat, sehingga bisa mengurangi tingkat kemiskinan.

Untuk variabel koefisien Gini (GR), dari persamaan regresi yang diperoleh dapat dijelaskan adanya hubungan yang berbanding terbalik antara perubahan koefisien Gini dengan kemiskinan. Terlihat koefisien regresi untuk variabel koefisien Gini (GR) negatif sebesar 5,590587. Hal ini berarti ada kecenderungan bahwa semakin tinggi ketimpangan pendapatan masyarakat di Kabupaten dan Kota yang ada di Jawa Barat, maka kemiskinan semakin rendah atau sebaliknya semakin rendah ketimpangan pendapatan masyarakat di Kabupaten dan Kota yang ada di Jawa Barat, maka kemiskinan semakin tinggi.

Model regresi kemiskinan (KEM) memiliki koefisien determinasi sebesar 92,20\%. Sehingga dapat dinyatakan bahwa posisi kredit perbankan, Pengeluaran pemerintah untuk belanja publik dengan proxy belanja modal, pertumbuhan penduduk, dan ketimpangan pendapatan masyarakat berpengaruh sangat tinggi terhadap tingkat kemiskinan di kabupaten dan kota di Jawa Barat.

Hasil uji model regresi yang diperoleh menunjukkan bahwa model regresi kemiskinan (KEM) diperoleh nilai F-statistic sebesar 117,161 dengan signifikansi sebesar 0,0000. Diperoleh nilai $F$ hitung ( $F$ statistic) lebih besar dari nilai $F$ tabel sebesar 2.405. Hasil yang diperoleh sejalan dengan nila signifikansi yang sangat kecil $(0,0000)$ yang berarti tingkat kesalahan untuk mengambil kesimpulan menolak Ho sebab lebih kecil dari $\alpha=0.05$ (5\%). Jadi dapat disimpulkan bahwa model regresi kemiskinan signifikan.

\section{SIMPULAN}

Hasil penelitian dapat disimpulkan bahwa:

1. Posisi kredit perbankan, Pengeluaran pemerintah untuk belanja publik dengan proxy belanja modal, pertumbuhan 
penduduk, dan ketimpangan pendapatan masyarakat berpengaruh signifikan terhadap tingkat kemiskinan di kabupaten dan kota di Jawa Barat.

2. Terdapat hubungan yang positif dan signifikan antara posisi kredit perbankan dengan tingkat kemiskinan di Kabupaten dan Kota di Jawa Barat.

3. Terdapat hubungan yang negatif dan signifikan antara pengeluaran pemerintah untuk belanja publik dengan proxy belanja modal dengan tingkat kemiskinan di Kabupaten dan Kota di Jawa Barat.

4. Terdapat hubungan yang positif dan signifikan antara pertumbuhan penduduk dengan tingkat kemiskinan di Kabupaten dan Kota di Jawa Barat.

5. Terdapat hubungan yang negatif dan signifikan antara ketimpangan pendapatan masyarakat yang diukur dengan koefisien Gini dengan tingkat kemiskinan di Kabupaten dan Kota di Jawa Barat.

\section{DAFTAR PUSTAKA}

Bidani, B and Ravallion. 1997. Decomposing Social Indicators Using Distributional Data. Journal of Econometrics: (77): 125-39.

BPS dan BAPEDA Provinsi Jawa Barat. PDRB Kabupaten/Kota di Jawa Barat Menurut Lapangan Usaha 2005 - 2015.

Dollar, D. and Kraay. A. 2000. "Trade, growth, and poverty". World Bank Policy Research. Working Paper No. 2615.

Fan, Shenggen, Peter Hazell and Sukhadeo Thorat. 1999. Linkages Between Government Spending.

Growth. and Poverty in Rural India. International Food Policy Research Institute. Washington. DC. Research Report. 110.

2007. Linkages Between Government Spending. Growth. and Poverty in Rural India and China. Food Policy For Developing Countries: The Role of Government In The Global Food System. Case Study 9-2.

Honohan, Patric. 2004. Financial Development. Growth and Poverty: How Close are the Links.

World Bank Policy Research Working Paper 3203. February 2004.

Jalilian, Hossein dan Colin Kirkpatrick. 2001. Financial Development and Poverty
Reduction in Developing Countries. Finance and Development Researh Programme. Working Paper.

Paper No. 30. Institute for Development Policy and Management. University of Manchester.

Kuncoro, Mudrajad. 2003. Ekonomi Pembangunan: Teori. Masalah. dan Kebijakan. Yogyakarta: UPP AMP YKPN.

Laabas, Belkacam and Imed Liman. 2004. Impact of Public Policies on Poverty. Income Distribution and Growth. Paper Prepared in the Context of the IFPRI/API Collaborative Research Project. Public Policy and Poverty Reduction in the Arab Region.

Lestari, Fatin Catur. 2008. Kemiskinan dan Pengeluaran Pemerintah untuk Infrastruktur. Studi Kasus Indonesia. 1976-2006.

Departemen Ilmu Ekonomi Fakultas Ekonomi dan Manajemen. Institut Pertanian Bogor. Juli 2008.

Odhiambo, Nicholas M. 2010. Financial deepening and poverty reduction in Zambia: an empirical investigation. International Journal of Social Economics. 37 (1): 41-53.

Pradhan, Rudra P. 2010. The Nexus Between Finance. Growth and Poverty in India: The Cointegration and Causality Approach. Asian Social Science. 6 (9): 114.

Thomas, Vinod, et.al. 2001. The Quality of Growth (Kualitas Pertumbuhan), diterbitkan untuk Bank Dunia, Jakarta, Gramedia.

Zhuang, Juzhong. et.al. 2009. Financial Sector evelopment. Economic Growth. and Poverty Reduction: A. Literature Review. ADB Economics Working Paper Series No. 137. 